\title{
Glasswort Powder Diet Activates Lipid Metabolism in Rat
}

Hyo Bin Seo ${ }^{1+}$, Yunyoung Kwak ${ }^{2 \dagger}$, Ju-Ock Nam², Young Ju Song ${ }^{3}$, Byung-Oh Kim ${ }^{4}$ and Sungpil Ryu ${ }^{1} *$

${ }^{1}$ Department of Leisure Sports, College of Ecology and Environmental Science, Kyungpook National University, Sangiu 742-711, Korea

${ }^{2}$ Department of Ecological Environment Conservation, Kyungpook National University, Sangiu 742-711, Korea

${ }^{3}$ Division of Sports Science, Sunmoon University, Asan 336-708 Korea

${ }^{4}$ Department of Applied Biology, Kyungpook National University, Sangju 742-711, Korea

Received February 7, 2012 /Revised March 28, 2012 /Accepted April 2, 2012

\begin{abstract}
The purpose of this study was to investigate the effects of glasswort powder intake on lipid metabolism. Rats were divided into three groups: a group fed a normal diet $(\mathrm{CON})$, one fed a high fat diet (HFC), and one fed a high fat diet with glasswort powder (HFG). They were fed their respective diet for four weeks. Body weight was significantly lower (9\%) in the HFG group than in the HFC group at the fourth week. According to the feces analysis, the HFG group showed the highest fat level $(120 \%$ vs. CON; $138 \%$ vs. HFC) and fecal calories $(110 \%)$. The concentration level of TG and LDL-C was $71.8 \%$ lower in the HFG group compared to the HFC group, while the concentration level of HDL-C was $152 \%$ higher in the HFG group. Expression of FABP in the liver was $197 \%$ greater in the HFG compared to the HFC group, with the expression of CPT-1 showing a similar tendency. These results suggest that glasswort powder intake suppresses weight gain and improves fat metabolism at the level of liver cells. From these results, we suggest that glasswort powder is effective against obesity by inhibiting the absorption of fat in the digestive tract.
\end{abstract}

Key words : Glasswort, obesity, fecal calorie, FABP, CPT-1

\section{Introduction}

Many problems associated with the obesity have become big social issues in the world. Therefore, a lot of countries are increasingly incurring socio-economic expenses in order to solve these problems. In addition, people are spending great amount of time and money to treat and prevent obesity. Among the solutions sought after to tackle obesity, there is a growing interest in health functional foods, which, in turn, is emerging as a new interest area for the food industry in Korea.

Glasswort (Salicornia herbacea L.) is a halophyte belonging to the chenopoidiaceae family and it has been known to grow naturally in the southwest coast of Korea. Since glasswort lives and grows in seawater, glasswort is rich in various mineral and amino acids and, in particular, contains large amount of dietary fiber $[15,20]$. In terms of the effects of glasswort, there are researches showing improvement of muscle strength [13], improvement of immune functioning $[12,24]$, antioxidant effects $[1,8,29]$, effects of inhibiting hy-

\footnotetext{
†This authors equally contributed this work.

*Corresponding author

Tel : +82-54-530-1434, Fax : +82-54-530-1439

E-mail : ryusp@knu.ac.kr
}

perglycemia and hyperlipidemia [21], anti-diabetic effects [16], effects of antibacterial activation [19], anticancer effects [25], and anti-inflammatory reaction [7] etc.. These studies, with results drawn from experiments using glasswort extract, glasswort fermented liquid, or glasswort pills, highly appreciated the potential value of glasswort as a functional food. Glasswort was classified as a master seafood by the National Fisheries Research and Development Institute.

On the other hand, with respect to lipid metabolism, a fatty acid binding protein(FABP) known as a protein that carries fatty acids into the cells, have been found as nine different kind so far [30]. It has been known that the expression of FABP is increased by a high-fat diet containing sucrose or with drugs that reduce blood lipids [5]. Hence, FABP is thought to play an important role in lipid metabolism [22]. In addition, according to a study with rats [4], FABP expression in the liver and small intestines increased after a long-term diet enhanced with dietary fiber. Given the fact that glasswort contains large amount of dietary fiber $[15,20]$, this suggests that the increase of FABP expression will lead to the increase of lipid metabolism. Also, the expression of carnitine palmitoyl transferase- 1 (CPT-1), which carries the long chain fatty acids to the mitochondria, is expected to increase along with the increase of lipid 
metabolism. Considering these findings, however, research related to glasswort is largely unknown. Thus, it is necessary to conduct various researches on glasswort as a functional food and, in particular, on research that relate the function of glasswort to the social issues of obesity. Accordingly, this study presents the potential anti-obesity effects of glasswort by investigating related variables to lipid metabolism when a high-fat diet added with glasswort powder is administered.

\section{Materials and Methods}

\section{Animal}

In this study, 4-week-old white Sprague-Dawley male rats (Orient Bio Inc. Korea) were used in the experiment. Rats were individually bred in the cage which was controlled to maintain an environmental temperature of $23-25^{\circ} \mathrm{C}$ and relative humidity at $60 \%$ with 24 hours of air circulation via forced ventilation. The light-dark cycle of the animal room was set at dark cycle from 08:00-20:00 and light cycle from 20:00-08:00. The rats were adapted to their environment for the first two weeks, and upon reaching 6-weeks of age, they were divided into three groups following a randomized block design. That is, the rats were divided into three separate groups for rearing; a control group (CON: normal diet control, $\mathrm{n}=8$ ), a high fat diet group (HFC: high-fat diet control, $\mathrm{n}=8$ ), and a high fat diet group with glasswort (HFG: high-fat diet with glasswort L., $n=8$ ). The glasswort power used in the experiment was made from glassworts collected at the Saemangeum tidal flats. Upon purchasing the glassworts, they were rinsed and processed into powder following a 10-day natural drying period and two days of heat drying period at $60^{\circ} \mathrm{C}$. The Regional Innovation Center at Kyungpook National University was commissioned to carry out the processing of glasswort powder for the experiment. A regular diet (AIN-76A) was provided with water for ad libitum during the first week of the preliminary breeding periods; a high-fat diet was provided upon the second week [26]. Glasswort diet was provided for four weeks in total. Glasswort powder was substituted for dietary fiber in 1:1 ratio and was added to the feed and water ingested with ad libitum During the breeding periods, body weight was measured once a week at assigned time. The increase rate of body weight was calculated by comparing before and after experiment data. The composition of each diet is shown in Table 1.
Table 1. Composition of experimental diet

\begin{tabular}{lccc}
\hline Constituent & CON & HFC & HFG \\
\hline Casein & 20 & 20 & 20 \\
Corn starch & 40 & 20 & 20 \\
Sucrose & 20 & 15 & 15 \\
Lard & 4 & 29 & 29 \\
Vitamin mix ${ }^{1)}$ & 1 & 1 & 1 \\
Mineral mix & 3.5 & 3.5 & 3.5 \\
Cellulose & 5 & 5 & - \\
D.L-methionine & 0.35 & 0.2 & 0.2 \\
Choline barbiturate & 0.15 & 0.2 & 0.2 \\
D.L-alpha-tocopherol & - & 0.1 & 0.1 \\
Corn oil & 6 & 6 & 6 \\
salicornia herbacea & - & - & 5 \\
\hline Total (g) & 100 & 100 & 100 \\
\hline
\end{tabular}

${ }^{1)}$ Vitamin mixture according to AIN-76.

${ }^{2)}$ Mineral mixture according to AIN-76.

CON: control group; HFC: high fat diet control group; HFG: high fat diet with glasswort group.

\section{Sample collection}

In order to examine the change in fecal amount, feces were collected and weighed on the 7th day of each week. In addition, in order to analyze the composition and calories of feces, fecal samples were collected one day before the sacrificing. The rats were put to 12 hours of fasting prior to the sacrificing and were anesthetized with ether prior to the opening of abdomen. After collecting the blood samples from the abdominal aorta using a syringe, epididymal fat, retroperitoneal fat, and the liver were extracted. Blood samples were separated via centrifugation (Hanil Science, Korea) at $700 \times g$ for 15 minutes; the top layer was only stored at $-70^{\circ} \mathrm{C}$ (Ilshin Science, Korea) for the future analysis.

\section{Lipids analysis in blood}

Levels of total cholesterol (TC), triglyceride (TG), and high density lipoprotein-cholesterol (HDL-C), were measured with the enzymatic quantification analysis kit (Asan Pharmaceutical, Korea) and calculated based on the formula provided with the analytic reagent and using the UV-mini-1240 spectrophotometer (Shimadzu, Japan). In addition, the low density lipoprotein-cholesterol (LDL-C) was calculated using the method presented in the previous study [19].

\section{Western blotting}

For the protein quantification of the fatty acid binding protein (FABP) and carnitine palmitoyl transferase-1 (CPT-1) 
in the liver, the liver tissue was mixed with $20 \mathrm{nM}$ Tris-cl, $5 \mathrm{mM}$ EDTA, $2 \mathrm{mM}$ PMSF, protease inhibitor cocktail (Sigma, St Louis, MO) for homogenization. After the centrifugation at 1,200× $g$ for $10 \mathrm{~min}$, the top layer was collected. Protein level of this layer was quantified according to the Bio-Rad protein quantification reagent method of use, and then, was made into samples by mixing Laemmli sample buffer. Such sample proteins of equal amount were separated using sodium dodecyl sulphate-polyacrylamide gel electrophoresis (SDS-PAGE) and were transferred to the polyvinylidenedifluoride (PVDF) membrane. Upon completion of transfer, they were blocked at room temperature for one hour using $5 \%$ bovine serum albumin (BSA) containing TBST buffer (50 mmol/l Tris- $\mathrm{HCl}, 150 \mathrm{mmol} / \mathrm{l} \mathrm{NaCl}$, and $0.05 \%$ Tween-20). The primary antibodies of FABP (Abcam, Cambridge, UK) and CPT-1 (Santa cruze Biotechnology, CA, USA) were diluted respectively at 1:1,000 and 1:200, and were incubated overnight at $4{ }^{\circ} \mathrm{C}$ and washed 5 times for 10 minutes with TBST ( $5 \%$ tween-20). The secondary antibodies were respectively diluted with goat anti-rabbit IgG (Santa cruze Biotechnology, CA, USA) at 1:2,000 and set for an hour to react, and then, washed 5 times for 10 minutes with TBST ( $5 \%$ tween-20). As for the identification of band of the deduced liver, an enhanced chemiluminescence (ECL) kit was used to obtain the fluorescent signal from the membrane on an X-ray film, with which the amount of certain proteins were determined using Densitometry (Bio-Rad, USA).

\section{Fecal analysis}

Regional Innovation Center at Kyungpook National University was commissioned to conduct the analysis on the composition ratio and calorie of the feces; analysis was repeated three times on each sample to minimize possible error. In short, the general composition analysis followed the measurement methods by the Association of Official Analytical Chemist: water content was measured at $105^{\circ} \mathrm{C}$ heat-drying in normal pressure; crude protein was measured with Kjeldahl method, crude fat was measured with soxhlet extraction method, crude ash was measured with dry ashing method; and crude fiber was measured with Fibertec system (Tecator AB., Switzerland). All measurements were expressed as percentage and the calories were calculated for each component. In calculating the matter of soluble nitrogen-free extract, components of moisture, crude protein, crude fat, crude ash, and crude fiber, were excluded.

\section{Data analysis}

Data were statistically analyzed with SPSS/PC 18.0 (SPSS Inc., USA). All test results were expressed as means and standard error. In order to verify the significance of each group, one-way ANOVA was conducted. Post hoc tests were conducted on any items that indicated significant difference using the least significant difference procedure. The significance levels were all set at $p<0.05$.

\section{Results}

\section{Changes of body weight}

In terms of changes in body weight during the experiment (Fig. 1A), HFG group showed a significant increase starting from the third week compared to HFC group. Also, HFG showed considerably higher amount of feces compared to the other two groups $(161 \%$ vs CON, $172 \%$ vs HFC; Fig. 1B). In addition, the epididymis fat (Fig. 1C), and retroperitoneal fat mass (Fig. 1D) with HFG group was significantly $73 \%$ and $84 \%$ lower compared to that of HFC group.

\section{Analysis of fecal composition}

Results from the contents analysis of feces collected from a combination of group samples throughout the experiment are shown in Table 2. There was no difference among groups in moisture content. However, HFC group showed the lowest protein contents while HFG showed the highest fat contents. Carbohydrate contents were $66 \%$ lower for HFG group compared to HFC group. Also, fiber contents were found more among HFG group than CON group, and ash contents were least found among HFG group.

In addition, results from the feces calorie difference among groups are shows in Table 3. Significant difference was found among groups in protein calorie while HFG group showed significantly higher fat calorie, $121 \%$ vs CON and $138 \%$ vs HFC, compared to the other two groups. Also, carbohydrates calorie was $66 \%$ lower for HFG group compared to HFC group, and the overall calorie was higher about $110 \%$ for HFG group compared to the other two groups.

\section{Changes of blood lipids}

For analysis of blood lipids, enzymatic colorimetry methods were applied. Results from the analysis of blood lipid composition are shown in Table 4 . TG level was $72 \%$ lower 

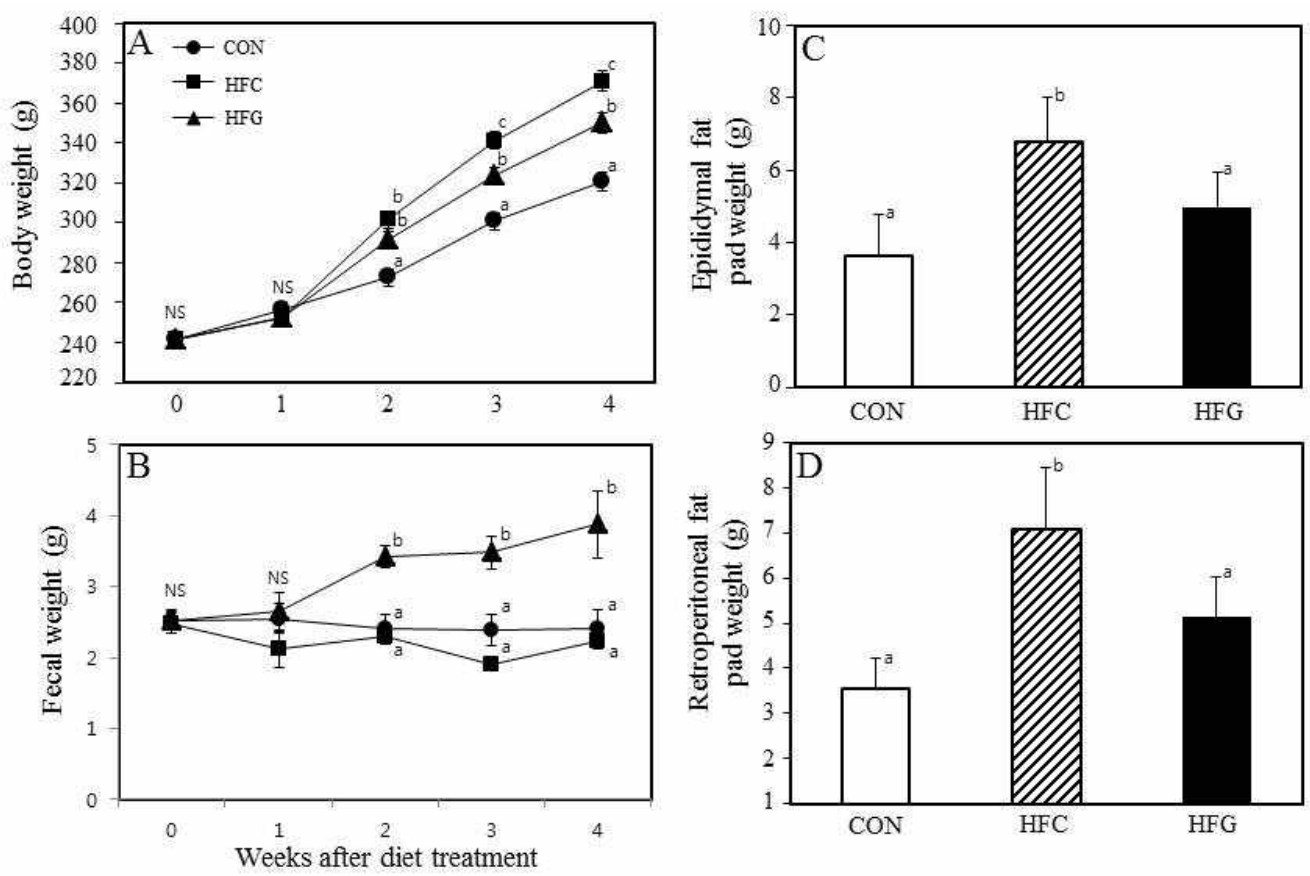

Fig. 1. Changes of body weight (A), fecal weight (B) during experimental periods, and epididymal fat pad weight (C), retroperitoneal fat pad weight (D) in rats. The results represent the means \pm SE. CON: control group (normal-diet supplements); HFC: high-fat diet supplement control group; HFG: high-fat diet with glasswort supplemented group. Different letters among the groups showed statistically significant at $p<0.05$, respectively.

Table 2. Differences of the fecal composition ratio for the last week of the experiment

\begin{tabular}{ccccccc}
\hline & Water & Protein & Fat & Carbohydrate & Fiber & Ash \\
\hline CON & $31.43 \pm 1.48 \mathrm{a}$ & $0.13 \pm 0.00 \mathrm{a}$ & $31.06 \pm 0.23 \mathrm{a}$ & $29.58 \pm 1.42 \mathrm{a}$ & $0.91 \pm 0.18 \mathrm{a}$ & $6.89 \pm 0.38 \mathrm{a}$ \\
HFC & $26.32 \pm 3.87 \mathrm{a}$ & $0.10 \pm 0.00 \mathrm{~b}$ & $27.20 \pm 0.54 \mathrm{a}$ & $38.46 \pm 7.84 \mathrm{a}, \mathrm{b}$ & $1.23 \pm 0.16 \mathrm{a}, \mathrm{b}$ & $6.69 \pm 0.63 \mathrm{a}$ \\
HFG & $31.64 \pm 1.48 \mathrm{a}$ & $0.12 \pm 0.00 \mathrm{c}$ & $37.52 \pm 1.98 \mathrm{~b}$ & $25.36 \pm 1.51 \mathrm{a}, \mathrm{c}$ & $1.43 \pm 0.12 \mathrm{~b}$ & $3.94 \pm 0.57 \mathrm{~b}$ \\
\hline
\end{tabular}

Values are mean \pm SE. All abbreviations were the same as the Fig. 1. Different letters within column means significance; $p<0.05$.

Table 3. Differences of the fecal calories

(kcal)

\begin{tabular}{ccccc}
\hline & Protein & Fat & Carbohydrate & Total \\
\hline CON & $0.52 \pm 0.02 \mathrm{a}$ & $279.50 \pm 2.04 \mathrm{a}$ & $118.31 \pm 5.69 \mathrm{a}$ & $398.33 \pm 5.24 \mathrm{a}$ \\
HFC & $0.40 \pm 0.00 \mathrm{~b}$ & $244.80 \pm 4.88 \mathrm{a}$ & $153.84 \pm 15.69 \mathrm{a}, \mathrm{b}$ & $399.04 \pm 16.17 \mathrm{a}$ \\
HFG & $0.48 \pm 0.00 \mathrm{c}$ & $337.61 \pm 17.1 \mathrm{~b}$ & $101.42 \pm 6.03 \mathrm{a}, \mathrm{c}$ & $439.63 \pm 14.02 \mathrm{~b}$ \\
\hline
\end{tabular}

Values are mean \pm SE. All abbreviations were the same as the Fig. 1. Different letters within column means significance; $p<0.05$.

Table 4. Differences of the blood lipid profiles

$(\mathrm{mg} / \mathrm{dl})$

\begin{tabular}{ccccc}
\hline & Triglyceride & Cholesterol & LDL-cholesterol & HDL-cholesterol \\
\hline CON & $17.67 \pm 1.17 \mathrm{a}$ & $44.42 \pm 1.16 \mathrm{a}$ & $21.57 \pm 1.25 \mathrm{a}$ & $19.32 \pm 0.84 \mathrm{a}$ \\
HFC & $29.53 \pm 2.03 \mathrm{~b}$ & $48.27 \pm 1.57 \mathrm{a}$ & $19.06 \pm 1.58 \mathrm{a}$ & $23.31 \pm 1.70 \mathrm{a}$ \\
HFG & $21.20 \pm 1.84 \mathrm{a}$ & $50.70 \pm 2.36 \mathrm{a}$ & $11.06 \pm 2.33 \mathrm{~b}$ & $35.40 \pm 1.29 \mathrm{~b}$ \\
\hline
\end{tabular}

Values are mean \pm SE. All abbreviations were the same as the Fig. 1. Different letters within column means significance; $p<0.05$.

for HFG group compared to HFC and LDL-C showed the same significance ( $51 \%$ vs CON and $58 \%$ vs HFC). HDL-C was $183 \%$ higher for HFG group compared to CON and
$152 \%$ compared to HFC, although no significant difference was found among groups in total cholesterol. 

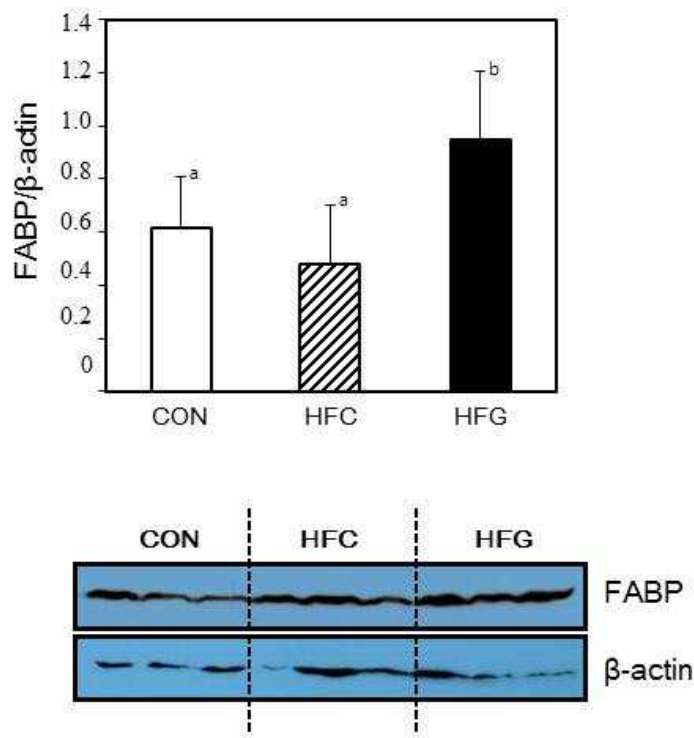

Fig. 2. Elevated FABP Expression levels in liver tissue of rats. Liver tissue lysates from the groups were analyzed by anti-FABP blotting. Levels of $\beta$-actin were used as a loading control (upper). Representative blotting with three of the six per group (lower). The results represent the means \pm SE. All abbreviations were the same as the Fig. 1. Different letters among the groups showed statistically significant at $p<0.05$, respectively.
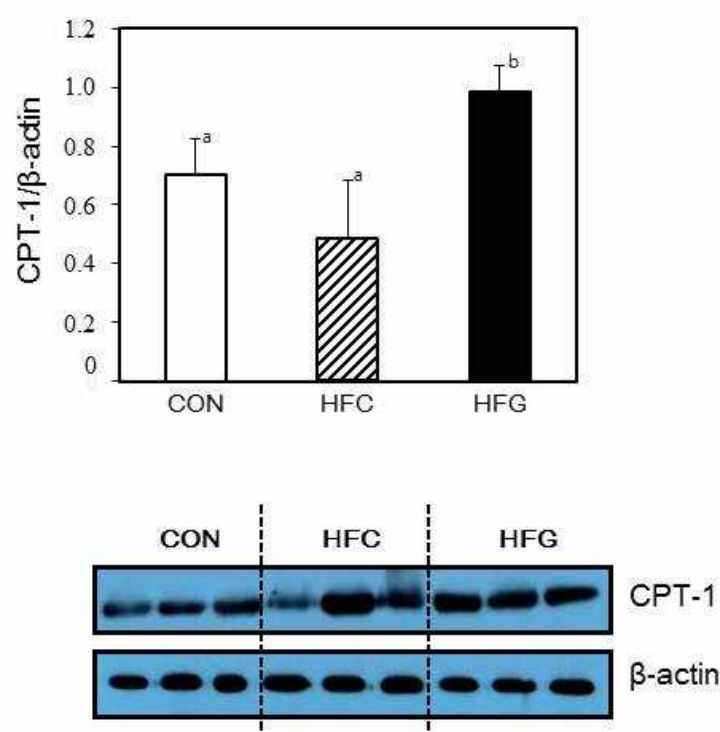

Fig. 3. Elevated CPT-1 Expression levels in liver tissue of rats. Liver tissue lysates from the groups were analyzed by anti-CPT-1 blotting. Levels of $\beta$-actin were used as a loading control (upper). Representative blotting with three of the six per group (lower). The results represent the means \pm SE. All abbreviations were the same as the Fig. 1. Different letters among the groups showed statistically significant at $p<0.05$, respectively.

\section{Expression of FABP and CPT-1}

FABP, the proteins that facilitate the transfer of fatty acids between extra- and intracellular membranes, and CPT-1, the proteins that facilitate the transfer of fatty acids into extra-mitochondria membranes, were analyzed by the western blotting methods. Expression of FABP (Fig. 2) was 197\% higher among HFG group compared to the other two groups and the expression of CPT-1 (Fig. 3) showed a significant increase from glasswort intake.

\section{Discussion}

This study investigated the potential effect of glasswort on anti-obesity through an experiment with rats subjected to a four-week diet including powdered glasswort processed from wild glassworts specifically found in the southwest coast of Korea. Polysaccharides extracted from glasswort were found to show anti-cancer effects when treated on colon cancer cells [25]. Also, anti-inflammatory activation was detected from examining the change of cyclooxygenase-2 when 3-caffeoyl-4-dicaffeoylquinic acid from glasswort was treated on macrophage RAW 264.7 cell of a mouse [7]. As seen in these studies, research using glasswort extracts are being carried out. However, in the present study, glasswort powder was used instead of glasswort extract so as to demonstrate the accessibility of glasswort for public use and to facilitate improved application of glasswort as a functional food.

In terms of body weight changes over the four-week diet including glasswort, body weight increased continuously but, after the three weeks, it was found that the growth rate was repressed for the HFG group compared to the control group. At the same time, the amount of epididymis and retroperitoneal fat was also found to be significantly lower with glasswort intake. This is thought to be the effects of large amount of dietary fiber contained in glasswort. Dietary fiber content in glasswort is very high at approximately 50 70\% and is effective for preventing constipation [25]. Results of changes in feces amount from the present study indicated that, starting from the second week of glasswort intake, HFG group showed a significant increase in feces amount compared to the other two groups as evidenced in the result showing that dietary fiber reinforced food intake effected more than twice increase of feces amount compared to the other groups [27]. Also, results from the components analysis of feces indicate that fat content is HFG group especially 
very high. Similar to the study that reported high level of cholesterol and TG found in the feces when glucan enhanced diet was consumed [27], results from calorie analysis of feces for this study showed that fat calorie was highest for HFG group and that total calorie was significantly higher HFG group by approximately $40 \mathrm{kcal}$ from glasswort intake. Thus, feed mix containing glasswort powder was found to inhibit the absorption of dietary fat ingested, resulting in the inhibition of weight gain and decrease of stored fat. Interestingly, considering the report regarding the maximum dietary fiber content in glasswort at 70\% [25], the dietary fiber content in the glasswort feed was relatively lower than the dietary fiber content in the control group feed since the substitution was made in the same amount. Hence, the fact that the current study yielded the same results as previous study despite with lesser amount of dietary fiber in the glasswort feed is quite notable and calls for further research in considering the amount of glasswort intake.

Meanwhile, considering the changes in blood lipids, TG concentrations were significantly lower for the CON group to the HFC group and HFG group. LDL-cholesterol concentration were significantly lower was in HFG group compared to that of HFC group. However, the overall cholesterol concentration did not show significant difference probably because the content level of HDL-cholesterol was improved by the intake of glasswort. When resistance exercise is paired up with glasswort intake, there was a decrease in the concentration of TG and an increase in the concentration of HDL-cholesterol [13]. Also, there is a report indicating that TG and cholesterol decreased for type 2 diabetic rats following a glasswort diet [9]. Similarly, study results showing that the concentration of TG in the liver and blood was significantly lowered among groups with high-sucrose intake group when water-soluble dietary fiber is added to the diet [23] and also that insoluble dietary fiber reduces the concentration of TG and cholesterol in the liver [17] highlighted the effects of dietary fiber. These results suggest that dietary fiber increases the activity of HMG-CoA reductase in the liver promoting the excretion of fat through increased synthesis of the bile and that it inhibits the synthesis of TG reducing the concentration of cholesterol and TG in blood [10]. Similarly, in another study, there was a significant decrease in LDL-cholesterol and systolic blood pressure among hypercholesterolemia patients following a long-term water-soluble dietary fiber intake, through which metabolic syndrome such as cardiovascular diseases was inhibited [28].
With regard to these various studies indicating the inhibitory effects of dietary fiber on metabolic diseases, the same results are expected with the present study since glasswort contains high level of dietary fiber.

Meanwhile, the FABP analyzed in this study is FABP 1 expressed in the liver which is also referred to as L-FABP. Of the FABPs, liver fatty acid binding protein is the most broadly distributed mammalian FABP and is expressed at very high levels in tissues most active in LCFA metabolism. Moreover, L-FABP directly interacted with CPT-1, exhibited saturable binding for CPT-1 with 1:1 stoichiometry and bound CPT-1 with high affinity [2]. Purified L-FABP removes substrate inhibition of CPT-1 by palmitoyl CoA [3]. In this study, the expression of FABP increased with the intake of glasswort, which, like the previous study [5], suggests that such phenomenon occurred because the blood lipid was reduced albeit not by drugs. Also, as seen in the previous study related to the FABP increase from dietary fiber intake [4] this result is thought to be affected by the promoted excretion of dietary fat into feces along with inhibited absorption into the system, leading to improvement of energy metabolism of fatty acids in the liver, although additional research is required in this matter. In addition, with respect to the mitochondrial influx of fatty acids, it was found in the present study that the expression of CPT-1 increased with glasswort intake. Study shows that when viscous dietary fiber is ingested, the expression of CPT-1B in the muscle increased significantly along with improvement in the level of stored fat [11]. Also, in another report, it was found that the stored fat level and TG concentration level decreased at the same time while the expression of CPT-1 increased following an 8 week of high-fat diet combined with fermented soybean paste [18]. These study results are similar to the results with FABP in our study. Similar trends with our study can also be found in the report about the decrease of stored fat and blood lipid concurrent with the increase of CPT-1 mRNA expression in hamsters subjected to a high-fat diet added with mangferin, the natural polyphenol that is effective for lipid reduction [6], and also in the study result about the increase of CPT- 1 expression and decrease of TG from black rice extract [31].

In conclusion, suppression of weight gain and reduction of stored fat and blood lipids level are considered to be the effects of glasswort intake, through which intestinal absorption of fat is inhibited while fecal excretion of fat is promoted resultantly lowering the calorie intake. In addition, it was 
determined that increased expression of FABP and CPT-1 further accelerated fat metabolism. These results suggest that, in the case of rats, glasswort intake may have an anti-obesity effect through activation of fat metabolism. It is expected that subsequent related research will be performed.

\section{Acknowledgment}

The part of this study was carried out with the support of 'Forest Science \& Technology Projects (Project No. S121010L080010)' provided by Korea Forest Service.

\section{References}

1. Ahn, B. K., Kim, R. D., Choi, B. and Kim, Y. S. 2011. Effect of Salicornia bigelovii extract on the activities of whitening and anti-wrinkle. Appl. Chem Eng. 22, 56-60.

2. Atshaves, B. P., Martin, G. G., Hostetler, H. A., McIntosh, A. L., Kier, A. B. and Schroeder, F. 2010. Liver fatty acid-binding protein and obesity. J. Nutr. Biochem 21, 1015-1032.

3. Bhuiyan, A. K. and Pande, S. V. 1994. Carnitine palmitoyltransferase activities: effects of serum albumin, acyl-CoA binding protein and fatty acid binding protein. Mol. Cell Biochem 139, 109-116.

4. Chapkin, R. S., Clark, A. E., Davidson, L., Schroeder, A. F. Zoran, D. L. and Lupton, J. R. 1998. Dietary fiber differentially alters cellular fatty acid-binding protein expression in exfoliated colonocytes during tumor development. Nutr. Cancer. 32, 107-112.

5. Glatz, J. F. C. and Veerkamp, J. H. 1985. Intracellular fatty acid binding proteins. Int. J. Biochem 17, 13-22.

6. Guo, F., Huang, C., Liao, X., Wang, Y., He, Y., Feng, R., Li, Y. and Sun, C. 2012. Beneficial effects of mangiferin on hyperlipidemia in high-fat-fed hamsters. Mol. Nutr. Food Res. 55, 1809-1818.

7. Han, E. H., Kim, J. Y., Kim, H. G., Chun, H. K., Chung, Y. C. and Jeong, H. G. 2010. Inhibitory effect of 3-caffeoyl-4-dicaffeoylquinic acid from Salicornia herbacea against phorbol ester-induced cyclooxygenase- 2 expression in macrophages. Chem Biol. Interact 183, 397-404.

8. Han, S. K. 2004. Antioxidant effect of fermented Salicornia herbacea L. liquid with EM (effective microorganism) on pork. Kor. J. Food Sci. Ani. Resour. 24, 298-302.

9. Hwang, J. Y., Lee, S. K., Jo, J. R., Kim, M. E., So, H. A., Cho, C. W., Seo, Y. W. and Kim, J. I. 2007. Hypolipidemic effect of Salicornia herbacea in animal model of type 2 diabetes mellitus. Nutr. Res. Pract. 1, 371-375.

10. Im, S. A., Kim, G. W. and Lee, C. K. 2003. Immunomodulatory activity of Salicornia herbacea L. components. Natural Product Sci. 9, 273-277.

11. Islam, A., Civitarese, A. E., Hesslink, R. L. and Gallaher, D. D. 2012. Viscous dietary fiber reduces adiposity and plas- ma leptin and increases muscle expression of fat oxidation genes in rats. Obesity 20, 349-355.

12. Jung, S. H., Park, K. U., Kim, J. Y., Park, C. K., Choi, K. S. and Seo, K. I. 2009. Biological activities of crude polysaccharides and crude saponins from Salicornia herbacea. Kor. J. Food Preserv. 16, 109-114.

13. Kang, B. Y., Jung, I. K., Chiang, M. H. and Lee, J. K. 2011. The influences of jointed Grasswort (Salicornia Herbacea L.) supplementation and combined exercise on body composition, muscle strength, bone mineral density and blood biochemical parameters in middle-aged women of 40 years. Kor. J. Physical Edu. 50, 211-223.

14. Kang, J. S., Kim, S. H., Kim, P. G., Lee, D. W. and Ryu, S. 2009. Differences of wood vinegar ingestion and exercise training on blood lipids, MDA, and SOD activities in rats. J. Life Sci. 19, 1190-1199.

15. Kim, H. S., Park, J. W., Lee, Y. J., Shin, G. W., Park, I. B. and Jo, Y. C. 2009. The amino acid content and antioxidant activities of glasswort (Salicornia herbacea L.). Kor. J. Food Preserv. 16, 427-434.

16. Kim, S. H., Ryu, D. S., Lee, M. Y., Kim, K. H., Kim, Y. H. and Lee, D. S. 2008. Anti-diabetic activity of polysaccharide from Salicornia herbacea. Kor. J. Microbiol. Biotechnol. 36, 43-48.

17. Krzysik, M., Grajeta, H., Prescha, A. and Weber, R. 2011. Effect of cellulose, pectin and chromium(III) on lipid and carbohydrate metabolism in rats. J. Trace Elem Med Biol. 25, 97-102.

18. Kwak, C. S., Park, S. C. and Song, K. Y. 2012. Doenjang, a fermented soybean paste, decreased visceral fat accumulation and adipocyte size in rats fed with high fat diet more effectively than nonfermented soybeans. J. Med Food 15, 1-9.

19. Lee, J. T. and An. B. J. 2002. Detection of physical activity of Salicornia herbacea. Kor. J. Herbology. 17, 61-69.

20. Nam, Y. K., Baik, J. A. and Chiang, M. H. 2007. Effects of different $\mathrm{NaCl}$ concentrations in the growth of Suaeda asparagoides, Suaeda maritima, and Salicornia herbacea. Kor. J. Soil. Sci. Fert. 40, 349-353.

21. Park, S. H., Ko, S. K., Choi, J. G. and Chung, S. H. 2006. Salicornia herbacea prevents high fat diet-induced hyperglycemia and hyperlipidemia in ICR mice. Arch Pharm Res. 29, 256-264.

22. Park, Y. S., Cha, M. H., Yoon, Y. S. and Ahn, H. S. 2005. Effects of low calorie diet and platycodon grandiflorum extract on fatty acid binding protein expression in rats with diet-induced obesity. Nutr. Sci. 8, 3-9.

23. Reimer, R. A., Grover, G., Koetzner, J. L., Gahler, R. J., Lyon, M. R. and Wood, S. 2011. The soluble fiber complex PolyGlycopleX lowers serum triglycerides and reduces hepatic steatosis in high-sucrose-fed rats. Nutr. Res. 31, 296-301.

24. Ryu, D. S., Kim, S. H. and Lee, D. S. 2008. Immunomodulating Activity of Salicornia herbacea Extract. Kor. J. Microbiol. Biotechnol. 36, 135-141.

25. Ryu, D. S., Kim, S. H. and Lee, D. S. 2009. Anti-proliferative effect of polysaccharides from Salicornia herbacea on induction of G2/M arrest and apoptosis in human colon can- 
cer cells. J. Microbiol. Biotechnol. 19, 1482-1489.

26. Seo, H. B., Lee, H. H., Lee, Y. K., Jeon, H. R., Jeon, B. D., Ryu, S. Kim, Y. B., Yoon, S. J. and Lee, S. C. 2008. Effects of soybean protein feeding and exercise training on blood lipids concentration, SOD and MDA in rats. Kor. J. Physical Edu. 47, 771-779.

27. Seog, H. M., Kim, S. R., Choi, H. D. and Kim, H. M. 2002. Effects of $\beta$-glucan-enriched barely fraction on the lipid and cholesterol contents of plasma and feces in rat. Kor. J. Food Sci. Technol. 34, 678-683.

28. Solà, R., Bruckert, E., Valls, R., Narejos, M. S., Luque, X., Castro-Cabezas, M., Doménech, G., Torres, F., Heras, M., Farrés, X. J., Vaquer, V. J., Martínez, M. M., Almaraz, C. and Anguera, A. 2010. Soluble fibre (Plantago ovata husk) reduces plasma low-density lipoprotein (LDL) cholesterol, triglycerides, insulin, oxidised LDL and systolic blood pressure in hypercholesterolaemic patients: A randomised trial. Atherosclerosis 211, 630-637.

29. Song, H. S., Kim, D. P., Jung, Y. H. and Lee, M. K. 2007. Antioxidant activities of red hamcho (Salicornia herbacea) against lipid peroxidation and the formation of radicals. Kor. J. Food Nutr. 20, 150-157.

30. Weisiger, R. A. 2002. Cytosolic fatty acid binding proteins catalyze two distinct steps in intracellular transport of their ligands. Mol. Cell Biochem 239, 35-43.

31. Yang, Y., Andrews, M. C., Hu, Y., Wang, D., Qin, Y., Zhu, Y., Ni, H. and Ling, W. 2011. Anthocyanin extract from black rice significantly ameliorates platelet hyperactivity and hypertriglyceridemia in dyslipidemic rats induced by high fat diets. J. Agric. Food Chem 59, 6759-6764.

\section{초록 : 함초분 첨가 고지방식이 흰쥐의 지방대사 연구}

서효빈 $^{1+} \cdot$ 곽윤영 ${ }^{2 \dagger}$. 남주옥 ${ }^{2} \cdot$ 송영주 ${ }^{3} \cdot$ 김병오 $^{4} \cdot$ 류승필 ${ }^{1}$

( ${ }^{1}$ 경북대학교 레져스포츠학과, ${ }^{2}$ 경북대학교 생태환경보전학과, ${ }^{3}$ 선문대학교 스포츠과학부, ${ }^{4}$ 경북대학교 생물 응용학과)

본 연구에서는 함초분 섭취가 지질대사에 미치는 영향을 알아보고자 하였다. 흰쥐를 일반식이 대조군(CON), 고지방식이 대조군( $\mathrm{HFC})$, 고지방식이에 함초분 첨가군 $(\mathrm{HFG})$ 로 각각 구분하여 4 주간 섭취시켰다. 체중은 $\mathrm{HFG}$ 가 $\mathrm{HFC}$ 에 비하여 $9 \%$ 정도 낮았다. 분변칼로리 분석을 한 결과, $\mathrm{HFG}$ 의 지방량(CON에 비하여 $120 \%, \mathrm{HFC}$ 에 비하여 138 )과 분변 칼로리(약 $110 \%$ )가 높은 것으로 나타났다. 혈중 중성지방과 LDL-C는 HFG가 HFC에 비하여 낮았으 며(각각 $71.8 \%$ 및 $58 \%$ ), HDL-C는 HFG가 HFC에 비하여 $152 \%$ 높았다. 간의 $\mathrm{FABP}$ 발현은 $\mathrm{HFG}$ 가 $\mathrm{HFC}$ 보다 $197 \%$ 높았으며, CPT-1 역시 동일한 경향을 보였다. 이러한 결과는 함초분 섭취가 체중의 증가를 억제하였고, 간 세포 수준에서의 지방대사를 개선하였다는 점을 시사한다. 이러한 결과를 함초분이 소화관에서의 지방흡수를 억 제함으로써 항비만 효과를 가지는 것으로 제안하고자 한다. 